\title{
THE IMPACT OF WELL-BEING AT WORK AND PSYCHOLOGICAL CAPITAL OVER THE TURNOVER INTENTION: A STUDY OF TEACHERS
}

\author{
ANGELO POLIZZI FILHO ${ }^{1}$ \\ (iD) https://orcid.org/0000-0001-9780-9065 \\ JOSÉ A. C. S. CLARO² \\ (iD) https://orcid.org/0000-0003-1319-2382
}

To cite this paper: Polizzi Filho, A., \& Claro, J. A. C. S. (2019). The impact of well-being at work and psychological capital over the turnover intention: A study of teachers. Revista de Administração Mackenzie, 20(2). doi:10.1590/1678-6971/eRAMG190064

Submission: Apr. 26, 2018. Acceptance: Aug. 30, 2018.

\footnotetext{
1 Universidade Paulista (UNIP), São Paulo, SP, Brazil.

2 Universidade Federal de São Paulo (Unifesp), Santos, SP, Brazil.
}

\section{(cc) BY




\section{ABSTRACT}

Purpose: To investigate a theoretical conceptual model for the intention of rotation, analyzing its relationship with well-being at work, psychological capital and intention of rotation.

Originality/value: The study contributed to present unpublished aspects and an apparent gap in the theoretical revision of the national literature by the absence of research investigating the relations between psychological capital and intention of rotation.

Design/methodology/approach: Research of empirical nature and quantitative approach. We tested four hypotheses regarding the interactions of the variables, using a self-completion questionnaire containing five validated and accurate Brazilian measures.

Findings: The hypotheses were confirmed, indicating that teachers have a well-being at work composed of greater satisfactions with colleagues, managers and tasks, and minors with salaries and promotions, medium indexes of involvement with work and affective commitment to the university in which they worked, revealing a low intention of rotation. In the international literature, the concept of psychological capital arises, proposing us future investigations and creating a line of research in Brazil in the measurement of the moderating role of psychological capital in the relations between constructs of organizational behavior. It is essential that other professional categories be studied in the search for evidence about the use of psychological capital as a moderating variable in the relation between the objective dimensions of this study.

\section{KEYWORDS}

Model of organizational behavior. Intention of turnover. Well-being at work. Psychological capital. University teaching. 


\section{INTRODUCTION}

The accelerating business dynamics, the constant changes in people management policies applied by organizations, and the complex networked business interactions seem to have visibly changed the emphases given by researchers to the facets of the behavior of practitioners working in organizations. Thus, among other topics, the planning that each professional make about his or her exit from the organization, called the Turnover Intention - TI (Vandenberg \& Nelson, 1999; Mowday, Porter, \& Steers, 1982) - has once again become a phenomenon of interest in the field of Organizational Behavior.

The purpose of this study is to test a theoretical conceptual model for TI in academics, analyzing covariables as Psychological Capital - PsyCap (Luthans, Luthans, \& Luthans, 2004) on Well-being at work - WBW (Siqueira \& Padovam, 2008) - and the possible impact on TI ; and researching in the universities the reasons why their teachers may tend to leave them and thus, alleviate the discomfort that would be generated, in people management, by the ignorance about the behavior in the organizational environment .

Competitiveness has been at the heart of organizations' concerns since the end of the millennium and in the focus of their managers since the global economic crisis of 2008. Mintzberg and Lampel (1999) argue that to cope with a highly competitive environment, survival, regardless of their size or sector, are required to promote strategic changes fast. In this context, organizational change has become routine, difficult to assimilate in the corporate world.

In this way, Masseto (2003) affirmed that Brazilian universities have left their social nature and are essentially pedagogical in character. The vision of 'education as commodity', adopted by business groups that now run most educational conglomerates in the country (Tiradentes, 2010), coupled with the 'sale' of quick job placement facilities provided by technology courses and the conveniences of distance education courses (Bertarello, 2010) approach the strategies of the corporate world. For Napolitano (2013), the business model of investment funds in the economic groups of education in Brazil, supported by public money, via Fund for Financing Higher Education Students (FIES [Programa de Financiamento Estudantil]) and the University Program for All (Prouni [Programa Universidade para Todos]) became "capitalism without risk", having captive clients and right recipe takes in its teachers to gain new positions in their organizational structures.

However, the training of these teachers did not include powers to take on these new roles, much less to keep up with the rapid growth of the sector, 
affecting the flow of the complex relations that inhabit the daily life of higher education institutions. For Masseto (2003), this has attracted the attention of people managers, who are concerned about the costs of turnover and the maintenance of talent, seeking greater competitiveness, many of them formed by the institution itself. Costs become even more serious when there is a loss of valuable and highly committed teachers (Chang, 1999), generating intangible costs.

On one hand, as specialists in the pedagogical training of higher education teachers (Masseto, 2003) and educators (Tiradentes, 2010; Bertarello, 2010) report the commercialization of higher education in Brazil or the generalized commodification of culture (Bourdieu, 1997). In turn, the Ministry of Education released promotional material informing that in recent years Brazilian education is already one of the three that has advanced the most in the way of quality around the world.

However, it was noted that the suspension of higher education entitlements to participate in FIES was due to the low-quality indicators established by the National System of Higher Education (Sinaes [Sistema Nacional da Educação Superior]) in the 2007-2009 period (Fommenti \& Paraguassú, 2011) and also in (Napolitano, 2013) converging with the authors opinion on the commodification of education (Masseto, 2003; Tiradentes, 2010; Bertarello, 2010; Bourdieu, 1997).

In the beginning of 2015, the national media reported that the Ministry of Education stipulated Higher Education Institutions to strict quality criteria in granting the FIES, considering the Courses General Index. The new rules could hurt the Higher Education Institutions that have most benefited from the model in recent years. Among the third enrollment champions by the FIES, 25 are evaluated with grade 3 (scale from 1 to 5) and only four have grade 4 Uninove, Unip, Unic, and Veiga Almeida. In June 2014, the Ministry of Education (MEC) through the Secretariat for Regulation and Supervision of Higher Education decoupled 28 Higher Education Institutions by the low academic quality, among them the Universidade Gama Filho (UGF) and the Centro Universitário da Cidade (UniverCidade), both in the city of Rio de Janeiro and a total of 10.8 thousand students enrolled.

With these initial weights, we can see that the study contributes significantly to the field of investigation of organizational behavior, when investigating psychological capital as a moderator of the relation between well-being at work and the turnover intention, making it relevant to the academy, besides presenting unpublished aspects and an apparent gap in the national literature, despite the limiting factor justified by the fact that, 
in Brazil, research into the proposed conceptual model is unprecedented, which makes it extremely difficult to publish published articles on the subject during the last five years. However, there are significant comparisons of studies of teachers, with Ferraz (2009) and Valente (2007) cited and compared in tables, in the text.

This study is composed, in addition to this introduction, by the theoretical basis, methodological aspects, research model, results in analysis and its presentation. Finally, the conclusions, contributions, limitations of the study and a proposal for the development of future research.

\section{LITERATURE REVISION}

This section is part of a brief theoretical review of the constructs of this research (WBW, PsyCap and TI). It is separated into two major parts, one presenting the concept of themes in the Organizational Behavior area and the other presenting recent research with teachers on each theme.

\subsection{Turnover intention - TI}

We studied the process that culminates with the planning of the college teachers exit. It is noteworthy that, the turnover phenomenon was not investigated in this study. According to Mowday, Porter, and Steers (1982), TI is the estimated (subjective) probability of individuals who will leave the organization at some point soon, in other words, TI was considered as a final cognitive variable that can immediately affect turnover (Chang, 1999), or rather, it is an immediate predictor of turnover.

This reference sought to justify the "desire" of teachers in universities to leave employment at some point in the future (Vandenberg \& Nelson, 1999), regardless the easiness in getting another job. In other words, teacher TI and Organizational Behavior involve variables, whether in microorganizational(individual character, personality, etc.), meso-organizational (interpersonal relationships, teamwork, etc.) or macro-organizational level (culture, climate, leadership, turnover, etc.).

In Brazil, Carmo and Oliveira (2010) investigated the organizational commitment affective calculative and normative; and employee confidence in the company as a precursor to TI. This relationship was explained especially by the organizational commitment of affective commitment, and then affective commitment. The authors concluded that the emotional bond with the enterprise reduces TI. 
In Portugal, studies on the interrelation of Quality of Life at Work (QLD) and TI concluded that organizations perceived by employees as those that offer a better QLD gain advantage in hiring and retaining people by reducing the TI of those who wanted to leave. That is, QLD can have a significant impact on individuals' behavioral responses, among with the TI reduction (Torres, 2010) stand out.

In China and Zhang (2009), he reviewed the significant turnover of professors in universities based on the perspectives of the institutional economy in force in the country. The conflict between schools and individuals has proved to be one of the main causes of turnover, regardless of basic issues such as survival and development. Wubin and Zhao Liang (2010) analyzed the moderating effect in PsyCap in the interrelation between the dimensions of burnout (emotional exhaustion, cynicism and personal fulfillment) and TI. The authors found out that most of the studies only pay attention to the single impact of a variable in the relationship between constructs when they should consider the existence of a moderating effect on the relation.

\subsection{Well-being or wellbeing at work - WBW}

Siqueira and Padovam (2008), based on the postulates of Seligman and Csikszentmihalyi (2000), constructed a theoretical model for WBW. The construct is based on three seminal concepts of the positive and pleasurable connotations in the work environment: satisfaction at work (Locke, 1976); involvement with work (Lloyd \& Kejner, 1965) and affective organizational commitment (Mowday, Steers, \& Porter, 1979). The authors, by integrating into said constructs, advanced at the same, since they have positive emotional connotations, pleasurable sensations and are pleasant, related to the organizational context. It is a positive state of mind experienced by the worker, through aspects present in the work environment (satisfaction and involvement with work) and positive feelings to the employer organization for having identified with the values and the ethics of it (affective commitment organizational).

The theoretical WBW model can be better understood by means of Figure 2.1, below. 


\section{(Figure 2.1)}

\section{THEORETICAL MODEL OF WBW}

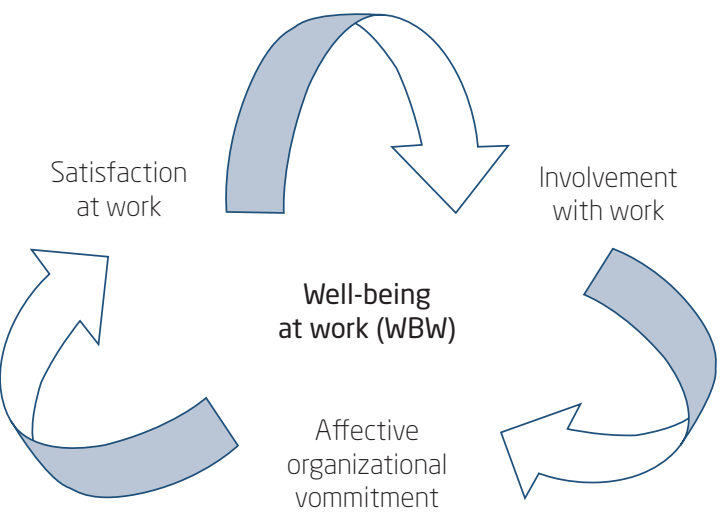

Source: Siqueira (2009, p. 250).

The first component of WBW, satisfaction at work, is defined by Siqueira and Padovam (2008) as a positive affective bond with work. The authors validate Siqueira and Gomide Jr. (2004) by pointing out that the pleasant evaluations have specific aspects obtained in the relationships with managers and colleagues, with the satisfaction provided by the salary paid by the company, as well as with the promotional units and their contentment with the tasks performed.

Involvement with work, the second dimension of WBW, was explained by Siqueira and Padovam (2008) as a concept constituted by the flow state conceived by Csikszentmihalyi (1999) in the organizational context of work, experienced when the individual experiences pleasant sensations resulting from it is elevated from the involvement maintained in the execution of the tasks, especially when challenges are attained by the individual's abilities, through clear transmission in the proposed goals and immediate return, provided by the activity performed. Thus, the activities look like the tasks that produce flow, triggering the full involvement and turning tasks in pleasurable activities, growing sensations resembling those of someone who plays artistic activity with talent (Siqueira \& Padovam, 2008).

The third and final component of WBW, affective organizational commitment, was designed by Mowday, Steers, and Porter (1979) as an identification of the worker with the organization and its objectives. In 1990, Mathieu and Zajac performed a critical reflection on history of the construct, with the statistical analysis of the results gathered from the researches 
carried out. The results, from the meta-analysis of the authors, converge and show that the commitment is superior for those who adhere to the work ethics. However, Meyer and Allen (1991) described a better model of Organizational Compromise, presenting three strands of commitment: affective, calculative and normative. Siqueira and Padovam (2008), despite corroborations with propositions, consider only the affective component of organizational compromise in their study.

Valente (2007) researched the WBW levels in physical education teachers from private schools and academies. The results indicate that they are happy individuals in their personal and professional life, regardless of the workplace. The researcher found that overall satisfaction with life is correlated with satisfaction at work, and consequently can generate affective attachment to work and low levels of TI, and thus increase levels of performance and productivity (Siqueira \& Gomide Jr, 2004).

Ferraz (2009) analyzed with the same focus of Valente (2007) the relations of WBW, however in teachers of the fundamental teaching. The results corroborated those of Valente (2000) when they indicated satisfaction at work. Teachers showed affective commitment to their schools, involvement with work, less absenteeism, greater commitment to the team, more organizational citizenship and less intention to leave the organization, or rather low TI (Siqueira \& Gomide Jr, 2004).

It is appropriate to compare the results of this study with those of Valente (2007) and Ferraz (2009), because they are studies with teachers, regardless of the educational context. Comparing the results in Figure 2.2, one must assume dissatisfaction at work provoked by the policies of people management; medium indexes of involvement with work; and an affective link with the organization. It was also found in all three studies that WBW experienced, regardless of the educational context, that this is not conditioned to material factors, but rather to a good level of relationship with people (colleagues and management). 


\section{(Figure 2.2)}

COMPARISONS BETWEEN FERRAZ JOB ( $N=209)$, VALENTE $(\mathrm{N}=124)$ AND POLIZZI $(\mathrm{N}=85)$

\begin{tabular}{|c|c|c|c|c|c|c|c|c|c|}
\hline \multirow{3}{*}{ Variables in WBW } & \multicolumn{9}{|c|}{ Works } \\
\hline & $\begin{array}{l}\text { Ferraz } \\
\text { (2009) }\end{array}$ & $\begin{array}{l}\text { Valente } \\
\text { (2007) }\end{array}$ & $\begin{array}{l}\text { Polizzi } \\
\text { (2011) }\end{array}$ & $\begin{array}{l}\text { Ferraz } \\
\text { (2009) }\end{array}$ & $\begin{array}{l}\text { Valente } \\
\text { (2007) }\end{array}$ & $\begin{array}{l}\text { Polizzi } \\
\text { (2011) }\end{array}$ & $\begin{array}{l}\text { Ferraz } \\
\text { (2009) }\end{array}$ & $\begin{array}{l}\text { Valente } \\
\text { (2007) }\end{array}$ & $\begin{array}{l}\text { Polizzi } \\
\text { (2011) }\end{array}$ \\
\hline & \multicolumn{3}{|c|}{ Averages } & \multicolumn{3}{|c|}{ Standard deviation } & \multicolumn{3}{|c|}{$T$ values } \\
\hline $\begin{array}{l}\text { Overall satisfaction } \\
\text { at work }\end{array}$ & 4.16 & 4.60 & 4.65 & 0.71 & 0.69 & 0.79 & 3.30 ** & - & $7.533^{* \star}$ \\
\hline $\begin{array}{l}\text { Satisfaction with } \\
\text { coworkers }\end{array}$ & 5.18 & - & 4.99 & 0.91 & - & 0.99 & $18.77^{\text {** }}$ & - & 9.271 ** \\
\hline $\begin{array}{l}\text { Satisfaction with } \\
\text { the boss }\end{array}$ & 5.14 & - & 5.37 & 1.20 & - & 1.06 & 13.70 ** & - & 11.858 ** \\
\hline $\begin{array}{l}\text { Satisfaction with } \\
\text { the tasks }\end{array}$ & 4.95 & - & 4.97 & 0.94 & - & 0.82 & 14.63 ** & - & 10.891 ** \\
\hline $\begin{array}{l}\text { Satisfaction with } \\
\text { salary }\end{array}$ & 2.62 & - & 4.16 & 1.12 & - & 1.26 & $17.82^{* *}$ & - & 1.149 \\
\hline $\begin{array}{l}\text { Satisfaction with } \\
\text { promotions }\end{array}$ & 2.92 & - & 3.71 & 1.32 & - & 1.31 & 11.79 ** & - & -2.007 \\
\hline $\begin{array}{l}\text { Involvement with } \\
\text { work }\end{array}$ & 4.07 & 4.52 & 4.15 & 1.31 & 1.27 & 1.31 & 0.79 & - & 1.028 \\
\hline $\begin{array}{l}\text { Affective } \\
\text { organizational } \\
\text { commitment }\end{array}$ & 3,20 & 3.68 & 3.68 & 0.91 & 0.73 & 0.71 & $3.17^{\star *}$ & - & 8.890 ** \\
\hline
\end{tabular}

${ }^{\star *} p<0.01$

Source: Elaborated by the authors.

In Figure 2.2, it can be seen that Valente (2007) researched the levels of WBW but did not examine its five individual factors (satisfaction with colleagues, satisfaction with management, satisfaction with tasks, satisfaction with salary and satisfaction with promotions), while Ferraz (2009) and Polizzi (2011) analyzing them.

The results of these researches have demonstrated that TI is strongly correlated with affective ties with affective commitment to school and with individual actions of teachers (absenteeism, performance and organizational citizenship) contributing to organizational effectiveness (Siqueira \& Gomide Jr, 2004). 


\subsection{Psychological capital - PsyCap}

The rationale behind the PsyCap proposed by Luthans, Luthans, and Luthans (2004) focuses on the understanding of Positive Organizational Behavior - POB. Initiated by Luthans (2002a, 2002b), it generated transformation and impact on the organizational environment to direct their research to the positive psychological capacities that could influence the performance of organizations and thus legitimizing the POB. The author, based on the foundations established by Seligman and Csikszentmihalyi (2000), emphasizes the need for a positive examination of Organizational Behavior, going beyond the popular management style based on self-help literature and the practice of managers for theoretically supported research in solutions to problems in the organizational world.

The four dimensions of PsyCap (self-confidence or self-efficacy, hope, optimism, and resilience) were scientifically specified, based on theoretical knowledge studies and solid empirical research by Luthans and his collaborators in isolated research in organizations and then assembled in an absolute form in the proposition of the PsyCap concept. Finally, positive psychology investigates the construction, reinforcement, promotion of human capabilities and forces which are measurable (Luthiers, 2002a). It is important to emphasize the existence of a possible overlap in the limits in the summaries of the presented definitions. Thus, for a still further understanding, it will be presented Figure 2.3, with the synthesis of the four dimensions of the concept.

\section{(Figure 2.3)}

\section{CONCEPTUAL DEFINITION OF THE FOUR DIMENSIONS OF THE CONCEPT}

\begin{tabular}{|c|c|c|c|}
\hline Affective state & Directionality & Concept & Main authors \\
\hline $\begin{array}{l}\text { Self-confidence } \\
\text { or effectiveness }\end{array}$ & $\begin{array}{l}\text { Related to } \\
\text { preparation both } \\
\text { with the present } \\
\text { challenges and } \\
\text { futures. }\end{array}$ & $\begin{array}{l}\text { Belief in the individual's capacity for action, will, } \\
\text { perseverance and intervention facing their } \\
\text { challenges and obstacles. It's the how much he } \\
\text { can develop, mobilize and raise your motivation, } \\
\text { your resources and their efforts to successfully } \\
\text { accomplish challenging and specific goals in a } \\
\text { given context. }\end{array}$ & $\begin{array}{l}\text { Bandura, 1997; } \\
\text { Luthans and } \\
\text { Youssef, 2004; } \\
\text { Maddux, 2002; } \\
\text { Luthans Avolio, } \\
\text { 2003; } \\
\text { Lopes \& Cunha, } \\
\text { 2005. }\end{array}$ \\
\hline
\end{tabular}




\section{(Figure 2.3 (conclusion))}

\section{CONCEPTUAL DEFINITION OF THE FOUR DIMENSIONS OF THE CONCEPT}

\begin{tabular}{|c|c|c|c|}
\hline Affective state & Directionality & Concept & Main authors \\
\hline Optimism & $\begin{array}{l}\text { Clearly expressed } \\
\text { for the future, } \\
\text { even making use } \\
\text { of of an event of } \\
\text { the present. }\end{array}$ & $\begin{array}{l}\text { Widespread expectation that there will be } \\
\text { positive events that will turn out to be positive, } \\
\text { due to the conditions which do not guarantee the } \\
\text { expected result in situations specific. } \\
\text { People credit success to themselves, distancing } \\
\text { themselves psychologically from negative events } \\
\text { and feeding themselves permanently of self- } \\
\text { esteem and enthusiasm. } \\
\text { Evidence in research suggests that it can be } \\
\text { developed by individuals. }\end{array}$ & $\begin{array}{l}\text { Luthans and } \\
\text { Youssef, 2004; } \\
\text { Martin-Krumm, } \\
\text { Sarrzon, Peterson, } \\
\text { and Famose, 2003; } \\
\text { Scheier and Carver, } \\
\text { 2003; } \\
\text { Lopes and Cunha, } \\
\text { 2005; } \\
\text { Seligman, } 1990 .\end{array}$ \\
\hline Hope & $\begin{array}{l}\text { Expressively } \\
\text { focused on the } \\
\text { future (goals and } \\
\text { short-term and } \\
\text { long-term plans). }\end{array}$ & $\begin{array}{l}\text { High determination, willpower, and alternatives to } \\
\text { investing energy to reach goals. Develop multiple } \\
\text { strategies that allow you to continue, without } \\
\text { losing focus, when obstacles and difficulties } \\
\text { arise. } \\
\text { The result of the interaction between Agency } \\
\text { (willpower) - how much the individual believes } \\
\text { to be able to achieve certain objectives. } \\
\text { Definition of plans (waypower) - how much the } \\
\text { individual is able to formulate effective plans to } \\
\text { achieve them. } \\
\text { It has a strong performance impact on a number } \\
\text { of variables at work, and studies also show that } \\
\text { it can be developed by people. }\end{array}$ & $\begin{array}{l}\text { Snyder et al. 1991; } \\
\text { Snyder, 2000; } \\
\text { Luthans et al. } \\
\text { 2005; } \\
\text { Snyder, Rand and } \\
\text { Sigmon, 2002; } \\
\text { Lopez et al. 2003; } \\
\text { Snyder et al. 1996; } \\
\text { Lopes and Cunha, } \\
\text { 2005. }\end{array}$ \\
\hline Resilience & $\begin{array}{l}\text { Focus on events } \\
\text { of the past, } \\
\text { empowering the } \\
\text { individual to the } \\
\text { present. }\end{array}$ & $\begin{array}{l}\text { Ability to recover from adversity and accept } \\
\text { reality as it is, believing that life can be lived } \\
\text { meaningfully. } \\
\text { Ability to improvise and adapt to changes, little } \\
\text { subjecting oneself to stress, crossing with vigor, } \\
\text { energy difficulties, and obstacles and, recovering } \\
\text { from conflicting and adverse situations, } \\
\text { maintaining the balance and increasing liability. } \\
\text { Ability to plan the future based on the present } \\
\text { difficulties, being characterized for good } \\
\text { results, despite the threats to development } \\
\text { or adaptation and can also be individual. }\end{array}$ & $\begin{array}{l}\text { Luthans and } \\
\text { Youssef, 2004; } \\
\text { Luthans, 2002b; } \\
\text { Rodriguez, 2005; } \\
\text { Barlach and Lisete, } \\
\text { 2005; } \\
\text { Anaut and Marie, } \\
\text { 2005; } \\
\text { Masten, 2001. }\end{array}$ \\
\hline
\end{tabular}

Source: Siqueira (2014).

The interest of the academy and the reasonable number of researches on PsyCap led Avey et al. (2011) to retrieve information on the evolution of the construct that integrated the characteristic of each of the four variables. 
Thus, the authors performed a meta-analysis by researching 51 types of research, aligning the conflicting effects produced by individualized studies. The results showed significant and positive empirical evidence between PsyCap and the WBW dimensions (job satisfaction and organizational commitment), strengthening the purpose of this research to investigate the PsyCap's moderating role in the relationship between WBW and TI.

\section{METHOD}

\subsection{Participants and location}

This research was carried out in a private university in São Bernardo do Campo, Metropolitan Region of São Paulo, Brazil. However, it is essential to point out that organizations distant from large urban centers have their own characteristics and peculiarities, concluded Leite and Albuquerque (2013) when searching, among other constructs, the talented professional's retention strategy in the North Region of Brazil.

This research was conducted with 85 university professors chosen by ed convenience and according to the data obtained. 57 were male $(67.1 \%)$. Age ranged from 24 to 71 years, with an average age of 45 years old $(\mathrm{SD}=11.49)$. The predominant marital status was married with $63.5 \% .58 .8 \%$ had master's degrees. The average working time was $8.13(\mathrm{SD}=6.88)$ years, ranging from 1 to 33 years. The working time between one and ten years represented $77.7 \%$ of the participants.

\subsection{Instrument}

A self-administered questionnaire was used, consisting of five measures that measured the study variables and were read and answered by the teacher without assistance.

The instrument was composed of the following measurement scales:

- PsyCap Scale (SPsyCap-12): Version summarized 12 items $(\alpha=0.83)$ and evaluates the personal strengths that pre-dispose to success at work.

- Occupational Satisfaction Scale (SOS): Reduced form from five factors with three items each: satisfaction with co-workers $(\alpha=0.81)$, satisfaction with salary $(\alpha=0.90)$, satisfaction with the leadership $(\alpha=$ $0.89)$, satisfaction the nature of the work $(\alpha=0.77)$ and satisfaction with promotions $(\alpha=0.81)$. 
- The Scale of Involvement with Work (SIW): Self-report scale composed of five items $(\alpha=0.78)$.

- Affective Organizational Engagement Scale (SAOE): The self-report measure, reduced form five items $(\alpha=0.93)$.

- Scale of TI (STI): Different from the previous ones, this scale was used in its full version and was made of three items $(\alpha=0.95)$.

To define the profile of the participants, additional data were added, such as age, sex, civil status, working time and academic training.

\subsection{Procedures and ethical aspects}

The approach was in the staff room, outside school hours, at a time in which they were all together. And so, collectively, they received an explanation of the purpose, voluntariness, discretion and the scientific character of the study, and were invited to participate in the research. Those who agreed were given the Free and Informed Consent Form, to sign their agreement. The Research Ethics Committee of the researched university analyzed and approved the project that met the requirements of the current legislation and obtained the Consubstantiated Opinion to the proposed research.

\subsection{Data analysis}

The analyzes incorporated the application of descriptive statistical analysis techniques, with standard deviations, Student's $t$-test, frequencies, $r$ (correlation coefficients), WBW, PsyCap and TI variables.

Multiple hierarchical linear regression models were also calculated by the enter method to confer the PsyCap moderating capacity on the WBW and TI ratio. Data analysis and treatment were performed by the Statistical Package for Social Science (SPSS), version 19.0, for Windows.

\section{MODEL}

The objective of this study intends by means of a theoretical conceptual model for TI to present, analyze and discuss the interdependence of the moderating variable PsyCap, on the dimensions that make up the independent variable WBW, and the possible impact of the dependent variable TI, in university professors. To better represent this objective, Figure 4.1, below, was elaborated for a better understanding. 
(Figure 4.1)

THE MODEL RELATIONSHIP BETWEEN WBW AND MODERATE TI BY PSYCAP $(\mathrm{N}=85)$



Source: Elaborated by the authors.

\section{RESULTS AND DISCUSSION}

First it will be presented, analyzed, interpreted and discussed the correlation indices (Pearson's $r$ ), among PsyCap, WBW, and TI. Several authors offer parterns for its for its interpretation, however, in this study we chose as parameters the criteria for force analysis of the correlations proposed by Bisquerra, Sarriera, and Martínez (2004, p. 146-148), including the interpretation $\mathrm{s}$ for negative coefficients.

The following are six regression models tested to investigate the role of the PsyCap moderator, the WBW, and the TI interrelationship through hierarchical analysis by multiple linear regression method enter.

\subsection{Descriptive analyzes}

The averages, standard deviations, frequencies, and percentages were calculated for all variables. The $t$-test was used to check that the average scores of each variable under examination significantly distanced from the midpoint of their respective scales inserted in response measures. The Pearson's $r$ was also calculated to verify the correlation of the coefficients between the model variables.

\subsection{Psychological capital (PsyCap)}

An average score of $4.04(\mathrm{SD}=0.55)$ was obtained, significantly higher than the midpoint (value $=3$ ) of the scale of responses from 1 to 5 . This result reveals that, on average, they tend to 'agree' with the 12 items of the Scale of PsyCap (SPsyCap), and therefore, they recognize that they 
have a relatively high PsyCap, that is, they have a relatively high positive mental state.

\subsection{Well-being at work (WBW)}

Descriptive analyzes were done on the three dimensions of WBW and its five individual factors (satisfaction with colleagues, satisfaction with management, satisfaction with tasks, satisfaction with salary and satisfaction with promotions).

Analyzing the average score of the general satisfaction variable at work, it was slightly above the midpoint $(=4)$ of the response scale (average $=4.65$, $\mathrm{SD}=0.79)$, based on the significant difference result signaled by the statistical test $(t=7,533, \mathrm{p}<0.01)$.

Satisfaction at work and the five related factors were also analyzed and the results indicated that only three averages of satisfaction with management (average $=5.37, \mathrm{SD}=1.06)$; (average $=4.99, \mathrm{SD}=0.99$ ) and satisfaction with tasks (average $=4.97, \mathrm{SD}=0.82$ ) are significantly different from the midpoint $(=4)$. Based on the results presented, it can be said that they tend to be satisfied with the leadership, with the colleagues and with the tasks that they perform. Therefore, they seem to be content with the understanding between them and their boss, the way their boss treats them, and the professional capacity of their manager.

There is evidence in the results that teachers tend to be satisfied with the collaborative spirit of their co-workers, with the friendship and trust that exist between them and pervading their relationships. Another source of satisfaction detected by the results was related to the task carried out regarding the interest that they arouse in their ability to absorb the teacher and the variety of them. While satisfaction with bosses, co-workers, and tasks have been observed, they position themselves around point 5 (satisfied) on a response scale that ranged from 1 (totally dissatisfied) to 7 (fully satisfied). These data point out that the satisfaction reported as high-level is not interpreted as they are not fully satisfied.

On the other hand, satisfaction with salary (average $=4.16, \mathrm{SD}=1.26$ ) and promotions satisfaction (average $=3.71, \mathrm{SD}=1.31$ ) were at a level near the midpoint ( $=4$, indifferent), on a scale ranging from 1 to 7 . The results tend to feel indifferent when they draw a parallel between their salary and the workload they carry out, their professional capacity and the efforts they make in a job. They were also indifferent and slightly inclined to dissatisfaction with the number of times they have already been provided in 
the institution, with the way in which the university that employs them carries out the promotion of their employees and with the opportunities envisaged to receive a promotion within this institution in the future. These results that deal with satisfaction with salaries and promotions refer to the sources of remuneration maintained by the university in its personnel management policy to reward the investments that the professor made in the institution. Thus, there is a gap in work satisfaction caused by the personnel management policies in force at the university.

The variable involving the work, measured by a one-dimensional scale, produced only one score (average $=4.15$; $\mathrm{SD}=1.31$ ) which was shown to have no significant difference $(t=1,028$; of the response scale (value $=4$ ). These results show that they would not be completely convinced $(4=$ neither agree nor disagree) to recognize that the greatest satisfaction of their lives come from work; they are not convinced that the hours spent on it are the best hours of their day; much less are the most important things in their lives linked to their work, and so little do they see themselves to be much attached to their work.

The content of these results seems to inform an indifference of the investigated ones regarding the affective bond that nourish by the tasks that they execute in the institution. For them to be considered teaching professionals highly involved in their work, a score of seven (fully involved) or statistically no different from them would be required. However, this was not the result. Faced with this logical conclusion, there is another gap observed in the well-being of those investigated, now provoked by a median index of involvement with work.

The affective organizational impairment variable produced a significantly different score (average $=3.68, \mathrm{SD}=0.71)(t=8,890 ; \mathrm{p}<0.01)$ from the midpoint of the response scale (value $=3$ ). With these results, it can be deduced that they tend to keep with the university where they work an apathetic affective commitment composed of medium feelings portrayed by pride, contentment, enthusiasm, interest, and animation for working in this university. We note a new gap in well-being caused by an affective bond with the median organization which failed to reach higher levels that could be interpreted as very or extremely committed.

In view of the results obtained and the interpretive analyzes drawn here on the content expressed through the responses to the instruments applied in the evaluation of WBW, it can be recognized that the positive and healthy state represented by WBW has gaps that compromise it, particularly produced by the average satisfaction with salaries and promotions, medium involvement with work and affective commitment to the university. 
The results confirmed a greater tendency in the occurrence of more considerable satisfaction levels with tasks, with co-workers and with the bosses and lower salary satisfaction scores and promotions. These findings are in line with the research by Valente (2007) with physical educators and Ferraz's (2009), with elementary school teachers. The need to compare these studies was made because they were studies with teachers, even in contexts other than the educational environment.

The averages, standard deviations and $t$ values of the works were compared, and it seems that there are no significant variations between the results of the three studies regarding WBW dimensions, tending to be equivalent, regardless of the level of teacher performance. Further studies could better investigate this assumption by comparing teacher samples from different sequences.

Still, in the comparison of the three studies, there is a possibility of assuming the same gaps in the three studies, that is, the dissatisfaction with work, provoked by the policies of people management; and medium indexes of involvement with work and affective bond with the organization. This assumption is reinforced by the results of this study and Ferraz (2009), who pointed to satisfaction with colleagues, management, and tasks, but dissatisfaction with salaries and promotions, resulting from the analysis of the five well-being factors at work.

It was also present in the three studies the fact that WBW experienced by teachers, regardless of the level of performance in elementary, middle or higher education, is not conditioned to material factors, but rather to a good level of relationship with people (colleagues and leadership) within the university.

\subsection{Turnover intention (TI)}

The average score calculated for TI reveals a level below the average (average $=2.18, \mathrm{SD}=-0.92$, midpoint $=3$ ) for a response scale of 1 to 5 . The $t$-test was also below $(-8,231)$ and the value was considered significant for $\mathrm{p}<0.01$. The results lead to the interpretation that respondents rarely think of leaving the university they work for (value $=2$ - rarely on a scale of 1 to 5 ).

Compared with the results obtained in the individual dimensions of WBW and as a whole, by the variable broad general satisfaction at work, it is observed that the dissatisfaction with the work provoked by the Human Resources Policies with regard to salaries and promotions, teachers rarely 
think, plan or will have to leave the Higher Education Institutions, or rather, there is low TI.

These findings are in agreement with Ferreira and Siqueira (2005), who tested a theoretical model for TI, which demonstrated that two variables of WBW, satisfaction at work, and affective organizational commitment were a direct antecedent of TI. There seems to be a similarity between the results of the researches regarding the scores of the WBW and TI dimensions. Therefore, the degrees of general satisfaction at work and affective organizational commitment are very close, and the professionals studied rarely think, plan or feel like leaving organizations that they work for, regardless the sector, time and conditions of the labor market.

The results of this study and those of Ferraz's (2009) showed a low tendency of TI. In general terms, they corroborated the Portuguese work developed by Torres (2010), by pointing out the relation of the different dimensions that make up QLD and its relationship with TI.

\subsection{Correlations}

In the following Figure 5.1, there are 15 computed correlations among PsyCap, WBW and TI. Positive and significant indices between PsyCap and all BWB dimensions and negative indices between these and TI are observed. All indices, in general, have a moderate correlation with each other, except for two correlations that reached low rates according to the same criteria of Bisquerra, Sarriera, and Martínez (2004, p. 146-148).

\section{(Figure 5.1)}

CORRELATION INDICES (PEARSON'S R) BETWEEN PSYCAP, THE WBW AND TI DIMENSIONS ( $=85$ )

\begin{tabular}{lccccc}
\multicolumn{1}{c}{ Variables } & 1 & 2 & 3 & 4 & 5 \\
\hline 1. Capital psychological & - & & & & \\
2. Satisfaction at work & $0.51^{* *}$ & - & & & \\
3. Involvement with work & $0.43^{* *}$ & $0.30^{* *}$ & - & & \\
4. Organizational commitment affective & $0.53^{* *}$ & $0.56^{* *}$ & $0.52^{* *}$ & - & \\
5. Turnover intention & $-0.30^{* *}$ & $-0.33^{* *}$ & $-0.36^{* *}$ & $-0.56^{* *}$ & - \\
\hline
\end{tabular}

** $p<0.01$ 
The results ranged from $r=-0.30$ to $r=0.56$, and the highest correlation coefficient found was in the ranged variables, Organizational Commitment affective, Satisfaction at work $(r=0.56$; $\mathrm{p}<0.01)$ and the lowest between TI and PsyCap ( $\mathrm{r}=-0.56, \mathrm{p}<0.01)$.

When analyzing the other correlations, it is noted that all WBW dimensions had a positive correlation with PsyCap, with all indexes reaching moderate correlation values. PsyCap presented positive, significant and moderate correlation with satisfaction at work $(r=0,51, \mathrm{p}<0.01)$; with involvement with work $(r=0.43, \mathrm{p}<0.01)$ and with affective organizational impairment $(r=0.53, \mathrm{p}<0.01)$. These results imply saying that PsyCap is higher, increase in proportion to the indicators of WBW. Thus, it is observed that PsyCap patients maintain a positive level of health at work, which is represented by WBW.

Finally, it appears that all the correlation coefficients between WBW and TI dimensions are negative. The RI presented negative, significant and with low correlation with satisfaction at work $(r=-0.33, \mathrm{p}<0.01)$; with involvement with work $(r=-0.36, \mathrm{p}<0.01)$, moderate but significant correlation with affective organizational commitment $(r=-0.56, \mathrm{p}<0.01)$. And these indexes assume one significant correlation active and negative between WBW and TI.

The greatest correlation with $\mathrm{TI}$ is the variable affective organizational commitment, making it the best possible predictor of TI, that is, the more affectively committed the worker is to the organization, the less he thinks, plans and has the will to leave it. the reverse also tends to be true. Finally, as PsyCap increases, the WBW indicators increase and the lower is TI. Therefore, teachers with the high PsyCap who have WBW tend not to plan to leave the universities in which they work.

\subsection{Model tests}

Six models were calculated to verify the ability of PsyCap to change the strength of the relationship between the three dimensions of WBW and TI, that is, to identify the moderating role of PsyCap in the interrelations of WBW and TI. The analyzes were developed by calculating for each of the three WBW dimensions two models of hierarchical multiple regression by the enter method (Figure 5.2). For each model, TI was the variable criterion, the three dimensions of WBW independent variables and PsyCap moderator variable. It was intended to identify the increment of each $\mathrm{R}^{2}$ calculated by the introduction of PsyCap in each model. 


\section{(Figure 5.2) \\ MODELS HIERARCHICAL LINEAR REGRESSION BY THE METHOD ENTER TO TI ( $\mathrm{N}=85)$}

\begin{tabular}{|c|c|c|c|c|c|}
\hline Models/steps/background & $B$ & $\mathrm{EPb}$ & $\beta$ & $R^{2}$ model & $\Delta R^{2}$ model \\
\hline \multicolumn{6}{|l|}{ Model 1} \\
\hline Satisfaction at work & -0.386 & 0.122 & $-0.329^{\star \star}$ & $0.097^{\star \star}$ & \\
\hline \multicolumn{6}{|l|}{ Model 2} \\
\hline Satisfaction at work & -0.277 & 0,141 & $-0.236^{\star \star}$ & $0.133^{\star \star}$ & 0.036 \\
\hline Psychological capital & -0.306 & 0.201 & -0.183 & & \\
\hline \multicolumn{6}{|l|}{ Model 3} \\
\hline Involvement with work & -0.252 & 0.072 & $-0.360 * \star$ & $0.119 \star \star$ & \\
\hline \multicolumn{6}{|l|}{ Model 4} \\
\hline Involvement with work & -0.198 & 0.079 & $-0.282^{\star \star}$ & $0.135^{\star \star}$ & 0.016 \\
\hline Psychological capital & -0.297 & 0.187 & $-0,180$ & & \\
\hline \multicolumn{6}{|l|}{ Model 5} \\
\hline Affective organizational commitment & -0.725 & 0.119 & $-0.557^{\star \star}$ & $0.302^{\star \star}$ & \\
\hline \multicolumn{6}{|l|}{ Model 6} \\
\hline Affective organizational commitment & -0.719 & 0,141 & $-0.553^{\star \star}$ & $0.294^{\star *}$ & -0.008 \\
\hline Psychological capital & -0.014 & 0.179 & -0.008 & & \\
\hline
\end{tabular}

** $p<0.01 ; p<0.05$

The first model calculated for TI had satisfaction at work as a single predictor with the capacity to explain $9.7 \%$ of the criterion variance $\left(\mathrm{R}^{2}=\right.$ 0.097, $\mathrm{F}(1.82)=9.951, \mathrm{p}<0.01)$. In the second regression model, when PsyCap was added as a moderating variable, the impact strength increased $\left(\mathrm{R}^{2}=0.112 ; \mathrm{F}(2.81)=6.215 ; \mathrm{p}<0.01\right)$, and the explanation of the impact was changed to $13.38 \%$. the variance of the planning to leave the university, had an increase order of $3.6 \%\left(\Delta \mathrm{R}^{2}=0.036\right)$.

In the third model for involvement with work, the power of explanation was $11.9 \%$ in TI $\left(\mathrm{R}^{2}=0.119 ; \mathrm{F}(1.83)=12.345 ; \mathrm{p}<0.01\right)$, that is, it explains more than the dimension satisfaction at work. In the fourth model, PsyCap added to engagement with the work and obtained a $13.5 \%$ explanation capacity $\left(\mathrm{R}^{2}=0.135 ; \mathrm{F}(2,82)=7.558, \mathrm{p}<0.01\right)$ augment of $1,6 \%$ in the explanation $\left(\Delta \mathrm{R}^{2}=0.016\right)$.

In the fifth model, affective organizational compromise presented the highest of the results, explaining $30.2 \%\left(\mathrm{R}^{2}=0.302\right.$, F $(1.83)=37.344$, $\mathrm{p}<0.01)$ in the TI. Finally, in the sixth and last regression model for affective 
organizational impairment with the inclusion of PsyCap, the explanatory power was $29.4 \%\left(\mathrm{R}^{2}=0.294, \mathrm{~F}(2.82)=18.452\right.$, $\left.\mathrm{p}<0.0\right)$. In this case, it is the only the WBW dimension that had its impact reduced by PsyCap $\left(\Delta \mathrm{R}^{2}=\right.$ -0.008), although by a small percentage of $0.8 \%$.

In general, the three WBW variables help explaining the TI of teachers in higher education. This explanation raises forcefully generated by the increase in the association of variables with PsyCap, except organizational commitment affective, in which the growth does not exist and, on the contrary, there is a reduction in the percentage of the variance explained. Therefore, affective organizational commitment is the WBW dimension that produces the greatest impact on TI, even with the reduction caused by the presence of PsyCap.

It is interesting to comment on the similarity of this study to that of Wubin; Zhao Liang (2010). While this research studied a positive health indicator (WBW), the Chinese authors studied a negative indicator of the individual's health condition (Burnout Syndrome). The Chinese study also concluded that PsyCap has to be considered as a moderating variable in TI studies. In conclusion, academics recommend that organizations invest in PsyCap training for their employees to develop the rational use of their human resources and to meet the fierce competition of the global market.

Finally, the meta-analysis developed by Avey et al. (2011), who studied 51 papers published in the last three years, validates the results of this research, as it relates to understanding the impact of PsyCap (variable moderator), affecting the strength and/or direction of the interrelationship WBW (independent variable) and TI (dependent variable).

\section{FINAL CONSIDERATIONS}

It can be concluded that the major objective of this study was attained in the way that model test conceptual theory for TI, among all the variables, showed significant negative and positive correlations revealing that PsyCap (moderator variable) affects the strength of the relationship between WBW (independent variable) and TI (dependent variable).

Based on the theoretical reference, the concept of TI is an effective indicator to judge a teacher in higher education, in his thinking, planning, and willingness to leave the university that he works for. Thus, understanding and controlling it is crucial to maintaining talent, a concern that worries people-management professionals. 
The WBW promotion can be perfectly carried out. However, disguised by the competitiveness that has become the center of the preoccupations in the universities, when they left their social nature and their essentially pedagogical character, approaching the strategies of the corporative world and marketed higher education in Brazil.

The concept of PsyCap emerges in the international literature as a relevant perspective to the research of topics in the business management of people. Its comprehensive features and structure can help in the development and training of human resources in organizations, which in turn can turn into a resource to be used in the fierce competitiveness of the educational market.

The study contributes to the field of investigation of Organizational Behavior. Positive points were revealed in the model test as an understanding of the important role of PsyCap as a moderator in the relationship between WBW and TI dimensions.

It has been observed that the more the teacher commits himself to the school, the less he thinks about leaving it. Thus, the good TI predictor is affective organizational commitment, because it has the greatest predictive force.

The contributions of this study are explained by the results similar to those of other studies with teachers, regardless of the educational context. Thus, through these new contributions, it is suggested to the Human Resources Areas to research the specific characteristics that have been identified to elaborate processes suited to their specific needs to promote WBW. It should be noted that such contributions will support the management practice and have the firm purpose of clarifying and attenuating TI effectively, retaining talents and maintaining the quality of the teaching staff, favoring competitiveness. Therefore, if the university wants to keep its teachers without plans to leave, it must act so that they are affectively committed to it.

Before finalizing, deficiencies of this research must be pointed out. The fact that the author taught in the faculty researched may have embarrassed some teachers and led them not to respond sincerely to the research, and some of them may even have refused. This assumption is based on the empirical finding of the low TI, although the indices of the WBW dimensions are indifferent.

Finally, it is important to continue the research with university professors. However, it is suggested to explore the issue and validate the results of this research with other professional categories, studied in the 
search for evidence about the PsyCap's role as a moderator variable in the interrelationship of the dimensions of WBW and TI. It would also be appropriate to present a research agenda with higher education professors in state and federal public universities, as well as in other Brazilian municipalities.

This work intends to contribute to the area of Organizational Behavior, broadening the knowledge about the TI phenomenon that has been troubling management policies.

\section{O IMPACTO DE BEM-ESTAR NO TRABALHO E CAPITAL PSICOLÓGICO SOBRE INTENÇÃO DE ROTATIVIDADE: UM ESTUDO COM PROFESSORES}

\section{RESUMO}

Objetivo: Investigar um modelo conceitual teórico para intenção de rotatividade, analisando sua relação com bem-estar no trabalho, capital psicológico e intenção de rotatividade.

Originalidade/valor: O estudo contribuiu ao apresentar aspectos inéditos e uma aparente lacuna na revisão teórica da literatura nacional pela ausência de pesquisas que investigassem as relações entre capital psicológico e intenção de rotatividade.

Design/metodologia/abordagem: Trata-se de pesquisa de natureza empírica com abordagem quantitativa. Testou quatro hipóteses relativas às interações das variáveis, utilizando um questionário de autopreenchimento contendo cinco medidas brasileiras validadas e precisas.

Resultados: As hipóteses foram confirmadas, indicando que docentes detêm um quadro de bem-estar no trabalho composto por satisfações maiores com colegas, chefias e tarefas, e menores com salários e promoções, índices medianos de envolvimento com o trabalho e de compromisso afetivo com a universidade em que atuavam, revelando baixa intenção de rotatividade. Surge, na literatura internacional, o conceito de capital psicológico, propondo-nos investigações futuras e a criação de uma linha de pesquisa no Brasil na mensuração do papel moderador do capital psicológico nas relações entre constructos do comportamento organizacional. 
É essencial que outras categorias profissionais sejam estudadas na busca por evidências acerca do uso de capital psicológico como variável moderadora na relação entre as dimensões objetivo deste estudo.

\section{PALAVRAS-CHAVE}

Modelo do comportamento organizacional. Intenção de rotatividade. Bem-estar no trabalho. Capital psicológico. Docência universitária.

\section{$\int$ REFERENCES}

Avey, J. B., Reichard, R. J., Luthans, F., \& Mhatre, K. H. (2011). Meta-analysis of the impact of positive psychological capital on employee attitudes, behaviors, and performance. Human Resource Development Quarterly, 22 (2). doi:10.1002/hrdq.20070

Bertarello, N. (2010). Emprego e democracia nas instituições particulares de ensino superior no Brasil. Revista O Professor, 14(14).

Bisquerra, R., Sarriera, J. C., \& Martinez, F. (2004). Introdução à estatística: Enfoque informático com o pacote estatístico SPSS. Porto Alegre, RS: Artmed, 2004, 146-148.

Bourdieu, P. (1997). Sur Ia télévision. Paris, FR: Liber Éditions.

Carmo, G., \& Oliveira, A. F. (2010, July). Antecedentes da intenção de rotatividade: comprometimento organizacional e confiança do empregado na organização. In Congresso Brasileiro de Psicologia Organizacional e do Trabalho at Universidade Metodista de São Paulo, São Bernardo do Campo, SP, Brazil.

Chang, E. (1999). Career commitment as a complex moderator of organizational commitment and turnover intention. Human Relations, 52(10), 1257-1278. doi:10.1023/A:1016908430206

Csikszentmihalyi, M. A. (1999). Descoberta do fluxo: A psicologia do envolvimento com a vida cotidiana. Rio de Janeiro, RJ: Rocco.

Ferraz, C. R. A. (2009). Percepção de suporte social e bem-estar no trabalho: Um estudo com Professores (Master's thesis). Universidade Metodista de São Paulo. Faculdade de Psicologia e Fonoaudiologia, Curso de Pós-Graduação em Psicologia da Saúde - São Bernardo do Campo. 
Ferreira, M. L. C. B., \& Siqueira, M. M. M. (2005). Antecedentes de intenção de rotatividade: Estudo de um modelo psicossocial. Organizações em contexto, $1(2)$.

Formenti, L., \& Paraguassú, L. (2011). Com nota baixa, 25\% dos cursos superiores perdem crédito estudantil. Retrieved from http://www.estadao.com.br/ noticias/geral,com-nota-baixa-25-dos-cursos-superiores-perdem-creditoestudantil-imp-,666011.

Leite, N. R. P., \& Albuquerque, L. G. (2013). Gestão estratégica de pessoas, estratégia de retenção de profissionais e comprometimento organizacional em uma estrutura organizacional remota. Revista de Administração da UFSM, 6(4), 803-822. doi:10.5902/198346597217

Locke, E. A. (1976). The nature and causes of job satisfaction. In M. P. Dunnette (Ed.), Handbook of I/O Psychology (12941349), Chicago, IL: Hand-McNally.

Lodahl, T. M., \& Kejner, M. (1965). The definition and measurement of job involvement. Journal of Applied Psychology, 49, 23-33. doi:10.1037/h00 21692

Luthans, F. (2002a). Positive organizational behavior: Developing and managing psychological strengths. Academy of Management Perspectives, 16(1), 57-72. doi:10.5465/ame.2002.6640181

Luthans, F. (2002b). The need for and meaning of positive organizational behavior. Journal of Organizational Behavior, 23 (6), 695-706. doi:10.1002/ job. 165

Luthans, F., Luthans, K. W., \& Luthans, B. C. (2004). Positive psychological capital: Beyond human and social capital. Business Horizons, 47(1), 45-50. doi:10.1016/j.bushor.2003.11.007

Masseto, M. T. (2003). Competência pedagógica do professor universitário. São Paulo, SP: Summus.

Mathieu, J. E., \& Zajac, D. M. (1990). A review and meta-analysis of the antecedents correlates, and consequences of organizational commitment. Psychological Bulletin, 108, 171-194.

Meyer, J. P., \& Allen, N. J. (1991). A three-component conceptualization of organizational commitment. Human Resource Management Review, 1(1), 61-89. doi:10.1016/1053-4822(91)90011-Z

Ministry of Education (2014). MEC descredencia Universidade Gama Filho e Centro Universitário da Cidade. Retrieved from http://portal.mec.gov.br/index.

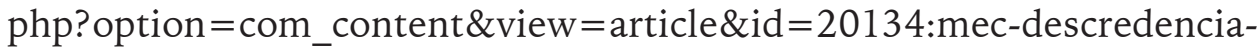
universidade-gama-filho-e-centro-universitario-da-cidade \&catid $=212$ : educacao-superior. 
Mintzberg, H., \& Lampel, J. (1999). Reflecting on the strategy process. Sloam Management Review, 21-30.

Mowday, R. T., Steers, R. M., \& Porter, L. W. (1979). The measurement of organizational commitment. Journal of Vocational Behavior, 14(2), 224-227. doi:10.1016/0001-8791(79)90072-1

Mowday, R. T., Porter, L. W., \& Steers, R. M. (1982). Employee-organization linkages: The psychology of commitment, absenteeism, and turnover. New York, NY: Academic Press.

Napolitano, C. (2016). Ensino superior privado foi debatido em São Paulo. Retrieved from http://www.fepesp.org.br/ensino-superior/noticias/ ensino-superior-privado-foi-debatido-em-sao-paulo

Polizzi Filho, A. (2011). O impacto de bem-estar no trabalho e de capital psicológico sobre a intenção de rotatividade: Um estudo com professores (Master's thesis). Universidade Metodista de São Paulo, São Bernardo do Campo, SP, Brazil.

Polizzi Filho, A., \& Siqueira, M. M. M. (2012). O impacto de bem-estar no trabalho e de capital psicológico sobre a intenção de rotatividade: Um estudo com professores. Anais do Congresso Nacional de Psicologia da Saúde, Promoção da Saúde e Doenças Crônicas: Desafios à Promoção da Saúde, Aveiro, Lisboa, Portugal.

Seligman, M. E. P., \& Csikszentmihalyi, M. (2000). Positive psychology: An introduction. Psychologist, 55(1), 5-14.

Siqueira, M. M. M., \& Gomide Jr, S. J. (2004). Vínculos do trabalhador com o trabalho e com a organização. In J. C. Zanelli, J. E. Borges-Andrade, \& A. V. B. Bastos (Orgs.), Psicologia, organizações e trabalho no Brasil (pp. 300-330). Porto Alegre, RS: Artmed.

Siqueira, M. M. M., \& Padovam, V. A. R. (2008). Bases teóricas de bem-estar subjetivo, bem-estar psicológico e bem-estar no trabalho. Psicologia: Teoria e Pesquisa, 24(2), 201-209.

Siqueira, M. M. M. (2009). Bem-estar no trabalho. In J. P. Cruz, S. N. Jesus, \& C. Nunes (Org.), Bem-estar e qualidade de vida: Contributos da psicologia da saúde (pp. 249-264). Portugal: Textiverso.

Tiradentes, A. (2010). A educação no novo milênio. Revista O Professor, year $\mathrm{V}(14), 12-13$.

Torres, J. M. B. C. P. (2010). Qualidade de vida no trabalho (QVT) e intenção de turnover: Efeito preditor de dimensões de QVT na intenção de turnover (Master's thesis). Universidade de Lisboa, Lisboa, Portugal.

Valente, L. E. (2007). Bem-estar subjetivo e bem-estar no trabalho em profissionais de educação física (Master's thesis). Universidade Metodista de São Paulo, São Bernardo do Campo, SP, Brazil. 
Vandenberg, R. J., \& Nelson, J. B. (1999). Desegregating the motives underlying turnover intentions: When do intentions predict turnover behavior? Human Relations, 52(10), 1313-1336.

Wubin, S., \& Zhao Liang, Y. (2010). Main effect and moderating effect of psychological capital in the model of employee turnover intention. Proceedings of the International Conference on Advanced Management Science.

Zhang, Z. (2009). An analysis on the turnover of college teachers in china from the perspective of institutional economics. International Education Studies, 2(1).

\section{AUTHOR NOTES}

Angelo Polizzi Filho, Postgraduate Program in Administration (PPGA), Universidade Metodista de São Paulo (Umesp); José A. C. S. Claro, Department of Social Communication, Universidade Metodista de São Paulo (Umesp).

Angelo Polizzi Filho is now Invited Professor of the Department of Business Administration at Universidade Paulista (UNIP); José A. C. S. Claro is now Professor of Institute of Marine Sciences at Universidade Federal de São Paulo (Unifesp).

Correspondence concerning this article should be addressed to José A. C. S. Claro at Rua José Caballero, 60, apto. 306, Gonzaga, Santos, São Paulo, Brazil, CEP: 11055-300.

E-mail: albertoclaro@albertoclaro.pro.br

\section{EDITORIAL BOARD}

Editors-in-chief

Janette Brunstein

Silvio Popadiuk

Associated Editor

Luciana Mourão Cerqueira e Silva

Technical Support

Vitória Batista Santos Silva

\section{EDITORIAL PRODUCTION}

Publishing Coordination

Irina Migliari

Layout Designer

Emap

Copyeditor

Irina Migliari (English)

Graphic Designer

Libro

Carlos Villarruel (Portuguese)

Language Editor

Daniel de Almeida Leão (English)

Irina Migliari (Portuguese) 